\title{
Reminiscences of Our Student Days
}

$\operatorname{AUTHOR}(S)$ :

Izawa, Kosei

\section{CITATION:}

Izawa, Kosei. Reminiscences of Our Student Days. Pan Africa News 2011, 18(special issue): 2-4

ISSUE DATE:

2011-09

URL:

http://hdl.handle.net/2433/147293

RIGHT:

Copyright (c) Pan Africa News. 
His passing cannot be mourned too much. He was a pioneer in the study of wild chimpanzees. Since 1965, he maintained research at Mahale, Tanzania, and accumulated accomplishments unique to his team, rivaling another longtime chimpanzee researcher, Dr. Jane Goodall whose work at Gombe is well known. He published many excellent papers, for example, on patrilineal structure of chimpanzee society, political strategy among males, and scientific documentation of newly discovered cultural behaviors. He was awarded the Leakey Prize and the International Primatological Society Lifetime Achievement Award. In addition, he served as President of the International Primatological Society. These honors tell how highly he was esteemed internationally.

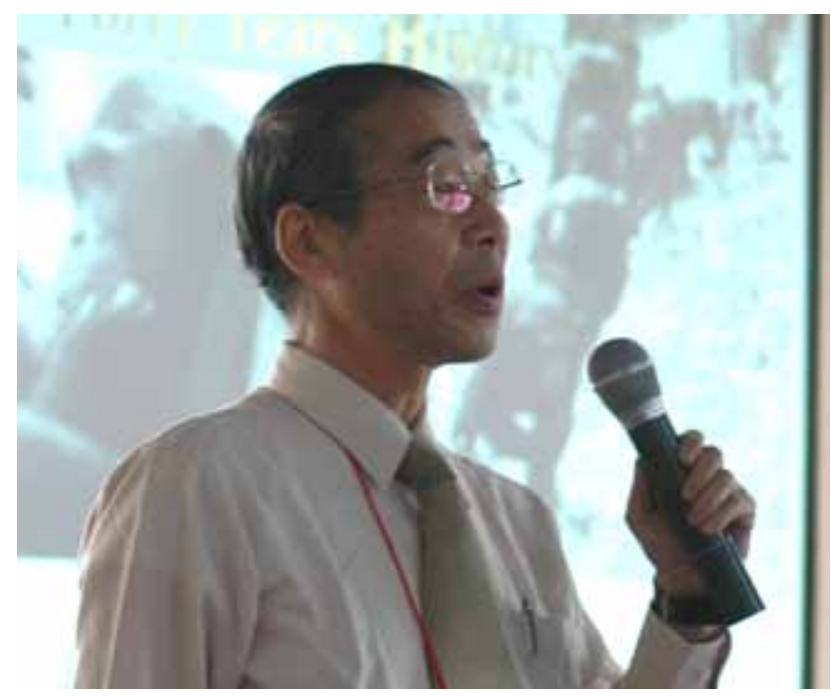

In 2004, he took up a new position as Executive Director of the Japan Monkey Centre (JMC). JMC is the place where Japanese primatology started and serves as a symbol for our discipline. I strongly recommended him as the best person for this position. The JMC hosts the World Primate Zoo and conducts museum activities such as social education, collection and preservation of materials, research, primate conservation, and publication of the international journal, Primates. Nishida-san, who had been eager to spread knowledge about primatology, took on his position energetically like a fish in water. Above all, his greatest achievement as Executive Director of the JMC was to enhance its international activities enormously. $\mathrm{He}$ advanced the research project for great ape conservation by the Ministry of Environment and set up the executive office of Great Apes Survival Project Japan Committee (GRASP-Japan) in JMC.

His strong mind commands my profoundest admiration and respect. He had to fight against a serious disease but successfully fulfilled his responsibilities as Executive Director of JMC, performed international activities, and continued to write vigorously. He trained many excellent students. I hope that they will collaborate in maintaining the chimpanzee research station at Mahale, and succeed as Nishida-san would have liked by advancing the project dynamically. May he rest in peace.

(English translation by Kazuhiko Hosaka)

\section{Tribute to Prof. Toshisada Nishida}

\section{Vernon Reynolds}

Oxford University, UK/Budongo Conservation Field Station

I first met Prof. Nishida ("Toshi" as we came to know him) on a visit to the Mahale Mountains chimpanzee project which I made in the late 1970s. I met up with my colleague Yuki Sugiyama in Dar es Salaam and we travelled across Tanzania to Kigoma. There we were supposed to meet a boat from the chimp project which would take us down Lake Tanganyika to Mahale. But it turned out that the boat's outboard motor was broken. We waited a few days during which we met Toshi and spent some time with him, talking about his work and the Mahale chimpanzees. Eventually I made it to the project where I met the team and the chimps. I did not know it, but I was quite seriously ill with hypothyroidism at the time and my lack of energy surprised the Japanese researchers, but they were kind enough to give me a slow and considerate field assistant to accompany me in the forest. I think we only met Toshi once during that trip, but owing to the thyroid problem I don't remember much about it.

Over the years, at conferences in Japan and elsewhere, I met Toshi again many times and was always impressed by his friendliness and total dedication to the cause of chimpanzees. I read his book on the Mahale chimpanzees, indeed it was given to us at one of those big IPS conferences in Japan.

Another occasion I remember well was in Paris, where a number of chimpanzee project leaders took part in a meeting at UNESCO headquarters to try and create a new category of "World Heritage Species", with the apes as the first species in that category. We had good discussions in which Toshi took a leading role. He was also good fun to be with in the little restaurants where we stopped during the days in Paris.

Above all he will be remembered for his work on the chimpanzees of the Mahale Mountains, a field site he set up and which continues to thrive at the present time. Only those who have set up a field site know how much work is involved, and Toshi was an indefatigable field worker who set the highest standards for his students. I recall him as a man who had that rare quality of acute observation without which it's impossible to be an astute fieldworker, and finally as a man who combined a firmness of purpose with a friendly outlook and disposition.

We at Budongo are all sorry to lose him, and send our condolences to his family.

\section{Reminiscences of Our Student Days}

\author{
Kosei Izawa \\ Professor Emeritus, Miyagi University of Education, Japan
}

For seven years (1961-1968), after I was admitted to the Department of Zoology, Faculty of Science, Kyoto University, until I completed my doctoral course, Nishidasan and I were together in the same lab, as if we had eaten out of the same pot all the time. During that period, 
Nishida-san was always several steps ahead of me both at work and privately, and I recall that I just followed his lead as if it were my lifestyle. Nishida-san was my best friend, whom I could not help admiring.

We had another contemporary at the lab, Takayoshi Kano-san, and Prof. Junichiro Itani was our supervisor. According to Sugio Hayama-san, an assistant professor at that time, one day at a drinking party, Prof. Itani told him about us three who had just started to study monkeys, "Well, Hayama, among these three, Nishida has a restless, academic turn of mind, Kano is a droll genius, and Izawa is a stubborn guy who is proud of his physical strength. Don't you think so?" When I heard this, I thought that he had fairly made the point!

Nishida-san chose Formosan macaques as the study species for his senior thesis in 1962. The monkeys had been released by the Japan Monkey Centre on Nojima Island, an uninhabited small island in Mikawa Bay. He intended to compare the Formosan macaques with the more well-studied Japanese macaques. I once stayed with him on this lonely island, so as to help him for 2 weeks when two typhoons passed by in succession in early September. We stayed in a small storehouse with wall-to-wall monkey feces. Our light was a candle. Our meal was a soup of limpets and barnacles from the sea, because the typhoons prevented the supply boat from getting to the shore. One night, he gave me a detailed explanation of the differences in male behavior between the two species. He was already quite familiar with Japanese monkeys, although he had not yet studied them. I clearly remember how amazed I was by his rich knowledge through his industrious reading of many papers, together with the terrible smell coming from the monkey feces there.

His study of male behavior bore fruit as his master's thesis, as is known by primatologists. He challenged daringly the theory of social structure in the Japanese monkey, which was thought to have been established. He revealed that solitary males (hanare-zaru) were a normal stage of the male life cycle; at that time, they were thought to be evicted males (murahachibu-zaru) or losers in fights for top-ranking status (bosu arasoi). Thus, he was the first to realize that monkey troops were not closed. It was more than 10 years after his epoch-making study that I somehow was able to contribute to the critique of the then-established theory of social structure in Japanese monkeys.

In March 1963, just after we finished our senior theses, Nishida-san and I made a 3-week expedition to search for "monkeys of the northern limit" (hokugen no saru), which was still mysterious at that time, in the southwestern part of Shimokita Peninsula. This project was carried out in collaboration with a film crew from the NHK TV program, "Japan Nature" (Nihon no shizen). Both filming and research were successful. Then Prof. Itani told us to compile a report, in order to apply to the Agency for the Cultural Affairs of Japan for designation of the monkeys as a natural monument. After the hard work of completing the report, while I was so tired and getting some alcohol for a break, Nishida-san, who did not drink at the time, was checking the designation process for all natural monuments in Japan. Moreover, he looked into and even memorized the laws and government ordinances concerned with natural monuments. Therefore, when we went to the Agency for Cultural Affairs, I remember that he was so persuasive that the officer in charge almost stammered. This memory of negotiation was definitely

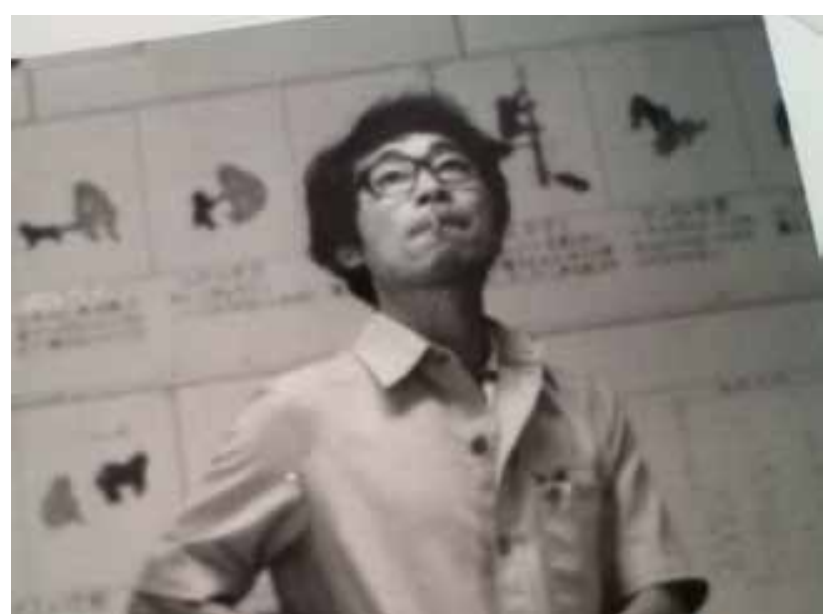

my starting point for conserving Japanese monkeys and at the same time for taking measures against their damage to agriculture and forestry.

In 1965, we both went to East Africa, for doctoral study of wild chimpanzees. After so many fruitless challenges, Nishida-san finally succeeded in provisioning chimpanzees and revealed many intelligent behaviors such as tool use. His findings were truly amazing, but I had to wait many more years until I succeeded in provisioning capuchin monkeys, the so-called "Chimpanzees of South America", and revealed some of their intelligent behaviors.

Nishida-san is known to have discovered that chimpanzees have a clear-cut unit-group even as they range daily in a fission-and-fusion manner and that their society is patrilocal. Again, this preceded my similar findings on the social structure of spider monkeys, done long after my capuchin research.

In this way, my stories about him are endless, for, as I have mentioned, Nishida-san was the person who always forced me to follow his steps.

This was the case even in job-hunting. While he was studying Formosan monkeys on Nojima Island, he already was thinking seriously about his future employment. Indeed, he once took an employment exam of the Asahi Shimbun Company (one of the leading daily newspaper companies in Japan). I thought his aptitude as a potential newspaper reporter had been fully utilized in preparing for the negotiations with the Agency for Cultural Affairs to make "monkeys of the northern limit" a natural monument. Of course, he found a job earlier than I. When he was hired by the University of Tokyo, I suddenly felt insecure of my future. At that time I had not outgrown yet the feeling of being a student. Now I recall it with nostalgia.

Ditto for marriage. In the summer of 1963, our first year in the master's course, one of our supervisors, Prof. Jiro Ikeda, took us on a training program for museum curators, where we did an archeological excavation in the suburbs of Misawa City, Aomori Prefecture. It was a oneweek joint program with other universities, such as Rikkyo University and Tokyo Women's Christian University. While I was happy just talking with charming female students from Rikkyo University during our free time, Nishida-san found his ideal woman among the intelligent, gentle, but obviously strong-minded students of Tokyo Women's Christian University. By the end of the training, he already had a conscious wish to marry her and he kept to it during all the time in Africa. He carried through his love and after coming back from Africa, he at last mar- 
ried the lady, Miss Haruko Kitayama. So for marriage, he again left me behind.

I vaguely believed that I would precede him in only one thing: entering the next world, for I have indulged in over-eating and over-drinking wherever I stayed, in Japan, Africa or the Amazon, without learning anything. That contrasted greatly with Nishida-san, but he preceded me even in this.

For me, he was an invaluable and truly great friend.

May his soul rest in peace.

(English translation by Noriko Itoh)

\section{Short Tribute to Prof. Toshisada Nishida}

\author{
William C. McGrew \\ Cambridge University, UK
}

Many will write of his scientific and academic achievements, which were great and many. Others will write of his commitment to Mahale, its chimpanzees, and its conservation. Here I wish to recall the pleasure of his company and his friendship, in a couple of personal memories:

Only three primatologists attended both WennerGren meetings on The Great Apes (1974, Burg Wartenstein, Austria; 1994, Cabo San Lucas, Mexico): Prof. Jane Goodall, Prof. Nishida, and myself. At the first one, he and I were almost the youngest persons there; at the second one, we were almost the oldest. We both occasionally enjoyed a celebratory alcoholic beverage. Laurie Obbink reminds me that after dinner on the first night at Cabo, Prof. Nishida bowed politely and asked her, "Please, where can we drink more?" She obliged, and we raised our glasses, more than once.

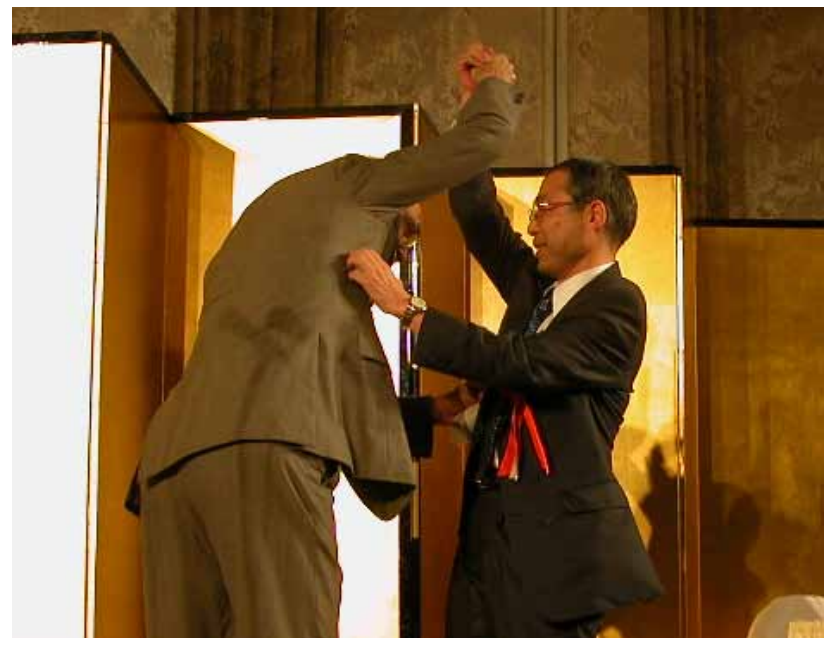

One time during one of the Understanding Chimpanzees conferences in Chicago, I took him to Wrigley Field to see the Cubs play. He admitted to not being a real baseball fan, though he recalled that his father had taken him to games. He paid attention during the play, and was appreciative of the atmosphere of that grand old stadium, but seemed a bit restless. It turned out that what he really wanted to do was stock up on souvenirs, such as baseball hats, pennants, etc., especially to do with Sammy Sosa (a famous Cub homerun hitter of that era). He did so, and we came away, with arms full.

Such are the small memories that never fade.

\section{Recollection of Nishida-san: His Days at the University of Tokyo}

\author{
Ryutaro Ohtsuka \\ Japan Wildlife Research Center, Japan
}

I remember that it was late autumn of 1969 that I met Nishida-san for the first time. He came to see the room of the ecological anthropology group. He had been recently been hired as a research associate in the Department of Anthropology at the University of Tokyo. Nishida-san arrived to take up the position in December of the year, and was promoted to Lecturer and Associate Professor afterwards. He worked in the same department until March, 1988. Thus, he taught at the University of Tokyo for over 18 years, or longer than the period he taught at Kyoto University.

Nishida-san joined the room occupied by the ecological anthropology group, which included the late Dr. Reizo Harako (doctor's course), Dr. Jun Takeda, and me (master's course). Only a few other research students and undergraduate students occasionally spent time in the room, since the ecological anthropology group had just started. We conducted a survey of the fishing communities and matagi hunters, but nobody had investigated the primates. It was only for four months that I was with Nishida-san in the Department of Anthropology, because the following April I became a research associate in the Department of Human Ecology at the University of Tokyo. However, the buildings were near to each other and we met frequently even after that.

Harako-san was a master of the room in the ecological anthropology group. He had been a surgeon but was attracted to the Pygmy people in Africa and was determined to learn anthropology. He was already over 30 years old then. Harako-san was a dominant personality, and Nishida-san was influenced by him. Talking over drinks was one habit instilled in us by Harako-san. At first, Nishidasan did not seem to understand why we went out to drink almost every day, but the frequency with which he joined us gradually increased. In fact, Nishida-san seemed to be more concerned about food than sake. Anyway, he ate a lot. Harako-san also encouraged Nishida-san to play go under his instruction. Nishida-san also became an avid player of the game. I will mention this again later. Let me add that Harako-san had a position of research associate in the Laboratory of Physical Anthropology, Kyoto University, for about eight years beginning in August, 1970.

Nishida-san often took postgraduate and undergraduate students to go to Mt. Takago on the Boso peninsula, Chiba Prefecture, to observe a troop of Japanese macaques, which was not fed by people any more. I also sometimes accompanied them. I remember that Nishidasan changed when he was there: he was full of vitality and walked very fast in the mountains. After Nishida-san began to work in Department of Anthropology, the number of postgraduates who majored in ecological anthropology increased. For instance, Dr. Taizo Iwano and Dr. Mariko Hasegawa (Hiraiwa), who specialized in primate ecol- 